\title{
A new Agyneta Hull, 1911 from northern Yakutia, Russia (Aranei: Linyphiidae)
}

\section{Новый вид рода Agyneta Hull, 1911 из Северной Якутии, Россия (Aranei: Linyphiidae)}

\author{
Andrei V. Tanasevitch \\ A.В. Танасевич \\ Institute of Ecology and Evolution, Russian Academy of Sciences, Leninsky prospekt, 33, Moscow 119071, Russia. E-mail: \\ tanasevitch@gmail.com \\ Институт проблем экологии и эволюции РАН, Ленинский проспект, 33, Москва 119071, Россия.
}

KEY WORDS: Spiders, Micronetinae, Arctic, Agyneta, new species.

КЛЮЧЕВЫЕ СЛОВА: Пауки, Micronetinae, Арктика, Agyneta, новый вид.

ABSTRACT. A new species, Agyneta bulavintsevi sp.n., is described from the environs of Tiksi, northern Yakutia, based on a single male. The new species seems to be most similar to the Fennoscandian-Siberian arcto-boreal $A$. trifurcata Hippa et Oksala, 1985, but differs well by the presence of a trichobothrium on metatarsus IV, as well as by some details of palpal structure.

РЕЗЮМЕ. Из окрестностей пос. Тикси (северная Якутия) по единственному экземпляру самца описан Agyneta bulavintsevi sp.n. Новый вид близок к фенноскандинавскому аркто-бореальному $A$. trifurcata Hippa et Oksala, 1985, от которого хорошо отличается наличием трихоботрии на предлапке IV, а также деталями строения пальпы.

\section{Introduction}

Checking the collections of the Zoological Museum of the Moscow State University, Moscow, Russia (ZMMU), I have recently come across a vial labeled as Agyneta sp., which contained a single male gained thirty years ago by Valery V. Bulavintsev from the environs of Tiksi (approximately $71.6340^{\circ} \mathrm{N} 128$. $8657^{\circ} \mathrm{E}$ ), on the coast of the Laptev Sea, Arctic Ocean. This species has proven new while its description is the subject of this paper.

\section{Material and methods} lection.

The type specimen is deposed in the ZMMU col-

In the description, the sequence of leg segment measurements is as follows: femur + patella + tibia + metatarsus + tarsus. All measurements are given in $\mathrm{mm}$. Scale line in the figures corresponds to $0.1 \mathrm{~mm}$.

The terminology of genitalic structures follows that of Saaristo \& Tanasevitch [1996].
The following abbreviations are used in the text and figures: E - embolus; EP — embolus proper; L lamella characteristica; Mt — metatarsus; R - radix; TA - terminal apophysis; TmI, TmIV — position of metatarsal trichobothrium on leg I and IV, respectively.

\section{Description}

Agyneta bulavintsevi sp.n.

Figs $1-8$.

HOLOTYPE $\sigma^{7}$ (ZMMU, Ta-7750, labeled as Agyneta sp.), RUSSIA, Yakutia, environs of Tiksi, VIII.1985, leg. V. Bulavintsev.

ETYMOLOGY. The new species is named in honour of the Russian conservationist zoologist, Valery V. Bulavintsev, who collected lots of material from the Arctic, including this species.

DESCRIPTION. $\sigma^{7}$. Total length 1.70. Carapace 0.73 long, 0.60 wide, dark brown with a grey, polygonal, median spot. Chelicerae 0.25 long, weak. Legs yellow-brown. Leg I, 2.00 long $(0.60+0.15+0.50+$ $0.45+0.30) ; \mathrm{IV}, 2.45$ long $(0.60+0.17+0.65+0.63+$ $0.40)$. Chaetotaxy. All tibiae with two dorsal spines; Mt I-IV spineless. Each metatarsus with a trichobothrium. TmI, 0.88, TmIV, 0.84. Palp (Figs 1-8): Tibia short, without outgrowths. Cymbium slightly conical. Paracymbium simple, posterior pocket tooth-shaped. Lamella characteristica very large, with two branches: upper branch serrate, narrower and shorter than lower one. Embolus without teeth at its base. Abdomen 1.00 long, 0.65 wide, dark grey, almost black.

Female unknown.

TAXONOMIC REMARKS. The new species seems to be most similar to A. trifurcata Hippa et Oksala, 1985 , but differs well by the presence of a trichobothrium on MtIV, as well as in shape of the lamella characteristica and embolus (cf. Figs 5-8 and 9-11).

DISTRIBUTION. Known from the type locality only. 


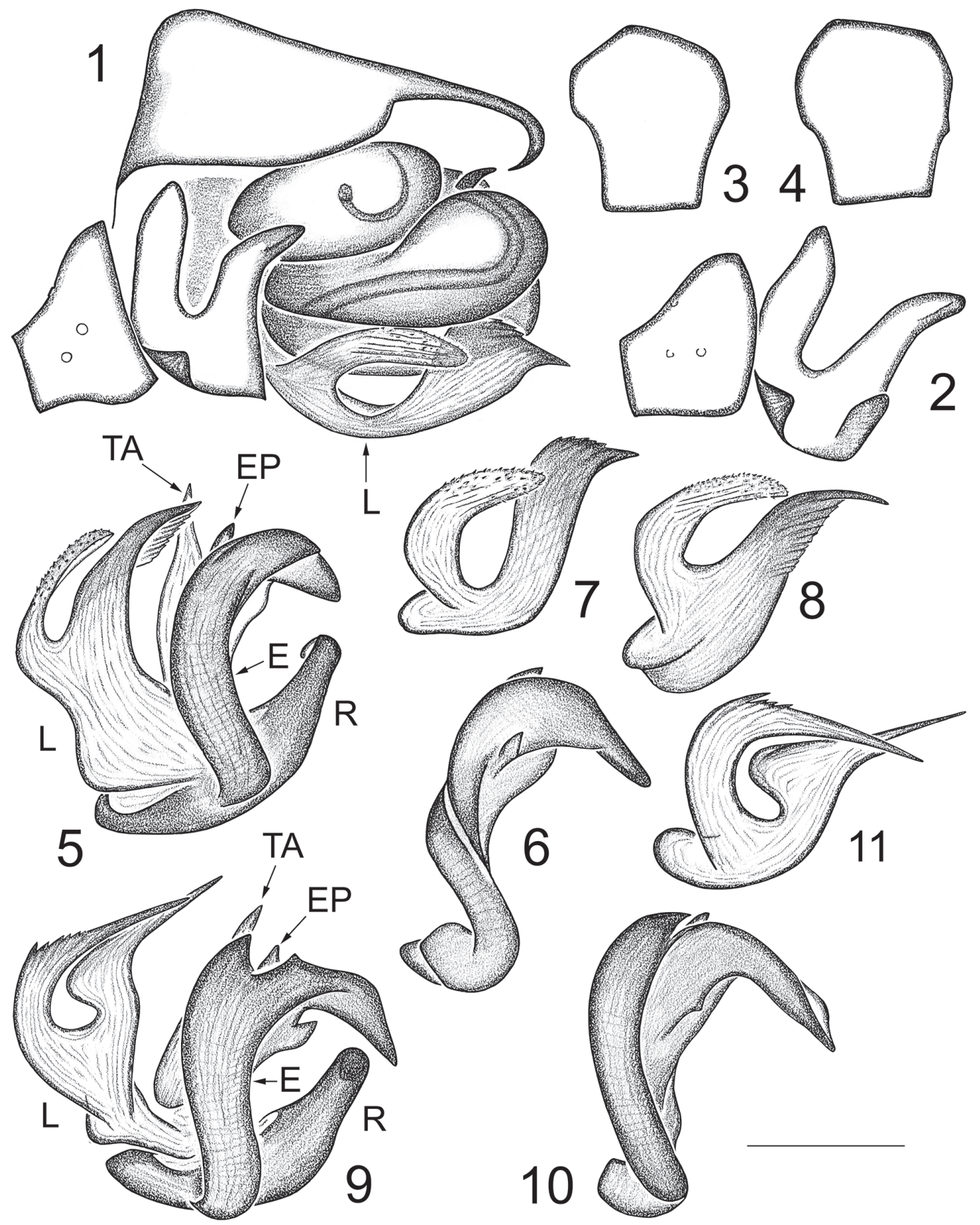

Figs 1-11. Agyneta bulavintsevi sp.n., holotype (1-8) and A. trifurcata Hippa et Oksala, 1985, specimen from Lake Ayan, Putorana Plateau (9-11). 1 - right palp; 2 - palpal tibia and paracymbium; 3, 4 - palpal tibia, dorsal view, different aspects; 5, 9 - embolic division; 6, 10 - embolus; 7, 8, 11 - lamella characteristica, different aspects.

Рис. 1-11. Agyneta bulavintsevi sp.n., голотип (1-8) и A. trifurcata Hippa et Oksala, 1985, экземпляр с оз. Аян, плато Путорана (9-11). 1 - правая пальпа; 2 - голень пальпы и парацимбиум; 3, 4 - голень пальпы, вид сверху, разные аспекты; 5, 9 эмболюсный отдел; 6,10 - эмболюс; 7, 8, 11 - ламелла, разные аспекты.

ACKNOWLEDGEMENTS. I am very grateful to Kirill Mikhailov (Moscow, Russia) for the opportunity to work with the ZMMU collections, as well as to Sergei Golovatch (Moscow, Russia) for editing the English of an advanced draft. This study was supported by the Russian Foundation for Basic Research, Project \#15-04-05964.

\section{Reference}

Saaristo M.I., Tanasevitch A.V. 1996. Redelimitation of the subfamily Micronetinae Hull, 1920 and the genus Lepthyphantes Menge, 1866 with descriptions of some new genera (Aranei, Linyphiidae) // Ber. nat.-med. Verein Innsbruck. Bd.83. S.163-186.

Responsible editor K.G. Mikhailov 